\title{
JEJARING KEBIJAKAN PENGANGKUTAN BATUBARA DI PROVINSI JAMBI DITINJAU DARI PERSPEKTIF GOOD GOVERNANCE
}

\author{
Ahmad Subhan \\ e-mail: ahmadsoebhan01̄yahoo.com
}

\begin{abstract}
ABSTRAK
Di balik kontribusi finansial untuk daerah, ternyata batubara juga menimbulkan permasalahan yang kompleks di Provinsi Jambi, yaitu dari sisi pengangkutannya. Mobilisasi truk pengangkut yang melewati jalan umum telah menimbulkan kerusakan di sepanjang ruas jalan yang dilalui meskipun sudah ada Peraturan Daerah yang melarangnya. Tulisan ini berusaha mengkaji masalah tersebut dari aspek kebijakan public, yaitu dengan menggunakan pendekatan jejaring kebijakan (policy network approach). Kajian ini menggunakan metode deskriptif dengan pendekatan kualitatif dengan mengandalkan data sekunder telah menemukan bahwa kompleksitas permasalahan pengangkutan batubara di Provinsi Jambi terlihat dari adanya pelanggaran Perda oleh pengusaha batubara sehingga masih merusak jalan umum, aksi demonstrasi sopir truk batubara, aksi protes blokir jalan oleh warga, dan upaya pengusaha unt uk mengugat Perda. Sumber permasalahannya yaitu karena adanya perbedaan kepentingan antara pemerintah daerah dengan pelaku usaha batubara. Sopir batubara menjadi alat pelaku usaha untuk melakukan respon ketidakpatuhanterhadapkebijakanPemda.Kuncipenyelesaiannyayaitupenegakkan hukum dan dukungan kebijakan dari pemerintah kabupaten terhadap kebijakan pemerintah provinsi.
\end{abstract}

Kata kunci: jejaring kebijakan, pengangkutan batubara, good governance.

\section{ABSTRACT}

Behind the financial contributions to the area, coal also raises transportation problems in Jambi province. Mobilization of trucks that pass through the public roads has caused damage despite existing regional regulations that forbid it. This brief paper examines that issue from public policy aspects by using the policy network approach. This study used descriptive qualitative approach by relying on secondary data has found that the complexity of coal transportation issues in Jambi province visible from regulation violations by coal's businessman that is still pass

86 CosmoGov, Vol.1 No.1, April 2015 
through public roads, demonstrations by coal truck driver, road blockage protests by residents, and efforts of coal's businessman to revise local regulation. Source of the problem is due to differences of interests between local government and business operators of coal. Key to the solution is law enforcement and policy support from district government towards the provincial government policies.

Keywords: policy network, coal transportation, good governance.

\section{PENDAHULUAN}

\section{Latar Belakang}

Keberadaan sumber daya alam yang berlimpah di suatu daerah bukan hanya dimaknai sebagai sumber pendapatan daerah saja namun juga mensyaratkan pengelolaan yang baik, berkelanjutan, dan memperhatikan aspek lingkungan hidup. Sinergi dan harmonisasi di antara seluruh pemangku kepentinganyang terlibat dalam pemanfaatannya, baik itu pemerintah, swasta, maupun masyarakat,menjadi katakunci keberlanjutan produktivitas dan keseimbangan lingkungan, termasuk sumber daya tambang batubara.

Batubaramerupakanpenyumbang devisa yang cukup besar bagi pendapatan negara dimana Provinsi Jambi adalah salah satu lumbung produksinya. Menurut Kementerian ESDM, melalui Peta Potensi Energi di Indonesia (2004), Provinsi Jambi memiliki potensi batubara yang belum dieksplorasi sebanyak 788.65 juta ton yang tersebar di beberapa kabupaten, antara lain: Bungo, Tebo, Tanjabbar, Sarolangun, Merangin, Batanghari, dan Muaro Jambi. Batubara merupakan bahan tambang utama di Provinsi Jambi, di samping minyak bumi dan gas. Produksi batubara sejak tahun 2007 hingga Mei 2012 di Provinsi Jambi mencapai 21,7 juta metrik ton. Jika dihitung dengan harga standar batubara di pasaran, USD 112/ton, maka penjualan batubara dari Provinsi Jambi menembus angka Rp 24 triliun.

Di balik kontribusi finansial untuk Daerah, ternyata batubara juga menimbulkan permasalahan yang kompleks di Provinsi Jambi, yaitu dari sisi pengangkutannya dari mulut tambang kestockpile. Trukpengangkut batubara yang berjumlah ratusan bergerak dari wilayah tambang di beberapa Kabupaten yang kebanyakan berada di area Barat Jambi menuju pelabuhan di area Timur Jambi. Mobilisasi truk pengangkut yang melewati jalan umum ini telah menimbulkan kerusakan di sepanjang ruas jalan yang dilalui. Kondisi jalan di Provinsi Jambi dengan daya dukung 8 ton tidak mampu menahan beban belasan hingga puluhan ton kendaraan pengangkut batubara.

Sejak tahun 2009, masalah jalan sebagai dampak pengangkutan batubara ini telah terjadi. Paling tidak 
ada beberapa dampak yang muncul, antara lain:

a. Kondisi jalan yang rusak akibat kelebihan muatan dan tidak sesuai dengan klasifikasi jalan yang ada di Jambi.

b. Kerugian finansial pemerintah daerah yang harus mengeluarkan dana yang besar untuk tambal sulam memperbaiki kondisi jalan yang rusak.

c. Banyak terjadi kecelakaan lalu lintas pada saat pengendara yang menghindari jalan yang berlubang.

d. Adanya pondasi rumah warga yang turun beberapa meter karena angkutan truk batubara melebihi kapasitas.

Menyikapi hal tersebut, pada tanggal 28 Desember 2012, disahkan Peraturan Daerah (Perda) Provinsi Jambi Nomor 13 Tahun 2012 tentang Pengaturan Pengangkutan Batubara dalam Provinsi Jambi. Perda ini mengatur setiap pengangkutan batubara dalam Provinsi Jambi wajib melalui jalan khusus atau jalur sungai. Kewajiban melalui jalan khusus harus siap selambat-lambatnya Januari 2014. Kebijakan ini memperlihatkan adanya tenggang waktu satu tahun yang diberikan kepada pelaku usaha untuk membuat sendiri jalan khusus pengangkutan batubara. Terlihat disini pihakpemerintahsudahmengakomodir kebutuhan pelaku usaha dengan memberikan toleransi bagi pelaku usaha untuk mempersiapkan jalan khusus agar tidak lagi melewati jalan umum. Langkah ini diambil sebagai kesepakatan bersama antara pihak pemerintah dan pelaku usaha pada saat mempersiapkan Perda tersebut.

Sebagai regulasi tambahan, Pemerintah Provinsi Jambi pada bulan Maret 2013 mengeluarkan Peraturan Gubernur (Pergub) Nomor 18 Tahun 2013 tentang Tata Cara Pelaksanaan Pengangkutan Batubara yang di dalamnya membentuk Tim Terpadu (Timdu) dalam rangka melakukan pembinaan, pengawasan, serta penindakan. Tim ini terdiri dari unsur Dinas Perhubungan, Dinas ESDM, TNI, POLRI, Satpol PP, dan unsur terkait lainnya. Setiap pelaku usaha yang melanggar ketentuan jalan khusus dan jalur sungai dikenai sanksi administrasi berupa pencabutan izin usaha pertambangan.

Tenggat waktu satu tahun berlalu dan ternyata jalan khusus belum terealisasi. Demikian juga jalur sungai sulit untuk dilalui karena sudah mengalami pendangkalan. Negosiasi dengan investor Asing mengenai pengerukan sungai Batanghari sempat dilakukan sejak tahun 2010, namun gagal. Sehingga konsekuensi yang muncul ialah aktivitas pengangkutan batubara masih melalui jalan umum. Dari sini titik awal terjadinya silang sengkarut masalah pengangkutan batubara di Provinsi Jambi pada waktu belakangan ini.

Sejak Januari tahun 2014, Timdu telah melakukan pengawasan penindakan dalam bentuk penilangan 
atas pelanggaran jalur pengangkutan batubara. Hal ini menimbulkan reaksi perlawanan dari pengusaha batubara yang bersikeras untuk tetap bisa melewati jalan umum. Mereka tetap mengoperasikan truk-truk pengangkut batubara melint as di jalan umum meski sudah dilarang. Tidak sampai disitu saja, pengusaha batubara juga mengancam akan menggugat Perda dan Pergub tentang pengangkutan batubara ke PTUN. Mereka beranggapan kebijakan itu semenamena, merugikan pengusaha dan melanggar perat uran yang lebih tinggi, yaitu Undang-Undang Nomor 22 Tahun 2009 tentang Lalu Lintas, dimana jalan nasional bukan menjadi kewenangandaerahuntukmengaturnya (Jambi Independent, 20/1/2014). Perlawanan pengusaha juga dilakukan dengan menggerakkan massa sopir truk batubara untuk melakukan aksi demonstrasi ke Kantor Gubernur Jambi. Mereka tidak hanya menggerakkan sopir, tapi juga membawa serta truk-truk masuk ke dalam kantor gubernur (Jambi Independent, 15/1/2014) . Selain itu, sopir batubara juga melakukan aksi pemblokiran jalan lintas Sumatera sebagai bagian dari protes.

Posisi tawar pengusaha batubara memungkinkan mereka melakukan resistensi terhadap kebijakan pemerintah. Kontribusi batubara terhadap pendapatan daerah cukup signifikan dimana ketentuan bagi hasil adalah 80 persen untuk daerah dan 20 persen untuk pusat. Pada tahun 2010, Provinsi
Jambi secarakeseluruhanmendapatkan jatah bagi hasil sebesar 55 miliar per tahun (Dinas ESDM, 2011). Resistensi pengusaha ini berlainan arah dengan pemerintah provinsi yang tetap menjalankan ketentuan Perda dan Pergub dimana Gubernur Jambi mengatakan bahwa penerapan kebijakan itu tidak bisa ditawar lagi karena sudah diberikan toleransi sebelumnya. Pihak DPRD Provinsi Jambi juga mendukung penegakan aturan tersebut (Jambi Independent, 20/1/2014).

Kebijakan pemerintah provinsi ini tidak terlepas dari pemerintah kabupaten/kota karena dalam Perda itu diatur bahwa bupati dan walikota harus membuat Peraturan Bupati (Perbup) dan Peraturan Walikota (Perwal) alur jalan yang diperbolehkan dilalui batubara. Dengan kata lain, kebijakan pemerintahprovinsijugamembutuhkan kebijakan pendukung di Kabupaten/ Kota sehingga kebijakan ini juga menyangkut hubungan antar level pemerintahan (intergovernmental relations).

Keadaan semakin problematis ketika warga masyarakat mulai bereaksi dengan melakukan aksi blokir jalan. Aksi ini telah terjadi berulang kali di beberapa desa yang menjadi lintasan truk pengangkut batubara. Warga bereaksi karena jalan umum sebagai fasilitas publik menjadi rusak, kenyamanan mereka terganggu, membahayakan keselamatan warga setempat, dan karena ketidakpuasan 
at as penegakan Perda. Peristiwaterkini adalah aksi pemblokiran jalan oleh warga terjadi pada tanggal 11 Maret 2014 di jalan Lingkar Selatan RT 28 Kebun Bohok Kelurahan Lingkar Selatan (Jambi Independent, 12/3/2014).

Paparan di atas menunjukkan adanya permasalahan kebijakan yang cukup kompleks dimana kebijakan pemerintah yang bersifat pengaturan (regulating) tidak dipahami dan dipatuhi secara utuh oleh pelaku usaha batubara sehingga menimbulkan dampak negatif pada kepentingan masyarakat umum terutama kerusakan infrastruktur jalan sebagai fasilitas publik. Tulisan singkat ini berusaha mengkaji secara lebih mendalam dari perspektif good governance, yaitu dengan menggunakan teori jejaring kebijakan (policy network).

Kebijakan ini penting untuk ditelaah lebih mendalam dengan perspektifjejaring mengingat beberapa hal, yait u pertama, adanya keterlibat an banyak aktor dari pemerintah, swasta, dan masyarakat dengan kepentingan masing-masing.Kedua, fenomena ini tidak hanya terjadi di Provinsi Jambi namun juga berpotensi terjadi di beberapa daerah penghasil batubara lainnya, seperti Sumatera Selatan, Sumatera Barat, Riau, Bengkulu, Kalimantan Timur, Kalimantan Selatan, dan Kalimantan Tengah. Ketiga, kajian dinamika kebijakan pemerintah daerah akan lebih lengkap dan memadai dengan adanya studi kebijakan dari pendekatan jejaring (network approach) mengingat tuntutan good governance dan demokratisasi di daerah.

\section{Rumusan Masalah}

Berdasarkan paparan di atas, maka dapat dirumuskan masalah yang akan dijawab dalam tulisan ini, yaitu bagaimana gambaran kompleksitas kebijakan pengangkutan batubara di Provinsi Jambi ditinjau dari jejaring kebijakan dalam konteks good governance?

\section{Tujuan Penulisan}

Artikel ini bertujuan untuk mengetahui kompleksitas kebijakan pengangkutan batubara di Provinsi Jambi dengan pendekatan jejaring kebijakan good governance.

\section{TINJAUAN PUSTAKA}

\section{Good Governance}

Pinto dalam Nisjar (1997:119) mengatakan bahwa governance adalah praktek penyelenggaraan kekuasaan dan kewenangan oleh pemerintah dalam pengelolaan urusan pemerintahan secara umum dan pembangunan ekonomi pada khususnya. Sementara itu, Hughes dan Ferlie, dkk., dalam Osborne dan Gaebler 
(1992), berpendapat bahwa good governance memiliki kriteria yang berkemampuan untuk memacu kompetisi, akuntabilitas, responsifterhadap perubahan, transparan, berpegang pada aturan hukum, mendorong adanya partisipasi pengguna jasa, mementingkan kualitas, efektif dan efisien, mempertimbangkan rasa keadilan bagi seluruh pengguna jasa, dan terbangunnya suatu orientasi pada nilai-nilai.

SedangkanLembagaAdministrasi Negara (2000:1) mengartikan good governance sebagai proses penyelenggaraan kekuasaan negara dalam melaksanakan penyediaan public goods dan services. Lebih lanjut ditegaskan bahwa apabila dilihat dari segi aspek fungsional, good governance dapat ditinjau dari apakah pemerintah telah berfungsi secara efektif dan efisien dalam upaya mencapai tujuan yang telah digariskan atau sebaliknya.

Konsep governancetidak sekedar melibatkan pemerintah dan negara, tapi juga peran berbagai aktor di luar pemerintah dan negara, sehingga pihak-pihak yang terlibat juga sangat luas. Governance adalah mekanisme pengelolaan sumber daya ekonomi dan sosial yang melibatkan pengaruh sektornegaradansektornonpemerintah dalam suatu kegiatan kolektif.

Unsur utama (domains) yang dilibatkan dalam penyelenggaraan pemerintahan (governance) terdiri dari 3 (tiga) komponen yakni:

\section{- $\quad$ The State}

Pada masa yang akan datang mempunyai tugas penting, yakni menciptakan lingkungan politik (political environment) guna mewujudkan pembangunan manusia yang berkelanjutan (sustainable human development) sekaligus meredefinisi peran pemerintah dalam integrasi sosial ekonomi, melindungi lingkungan, kemiskinan, menyediakan infrastruktur, desentralisasi dan demokratisasipemerintah, memperkuat finansial dan kapasitas administrasi Pemerintah Daerah. Disamping itu, Pemerintahjuga perlumemberdayakan rakyat (empowering the people) yang menghendaki pemberian layanan, penyediaan kesempatan yang sama secara ekonomi dan politik. Pemberdayaan tersebut akan terwujud apabila diciptakan suatu lingkungan yang kondusif dengan sistem dan fungsi yang berjalan sesuai dengan peraturan yang jelas.

\section{- $\quad$ The Private Sector}

Memiliki peranan penting karena lebih berorientasi kepada pendekatan pasar (market approach) dalam pembangunan ekonomi serta berkaitan dengan penciptaan kondisi dimana produksi barang dan jasa (good and services) dalam lingkungan yang kondusifuntukmelakukanaktivitasnya dengan lingkup kerja "incentives and rewards" secara ekonomi bagi individu dan organisasi yang memiliki kinerja baik. 
- Civil Society

Merupakan wadah yang memfasilitasi interaksi sosial dan politik yang dapat memobilisasi berbagai kelompok didalam masyarakat untuk terlibat dalamaktivitassosial,ekonomi, dan politik sekaligus melakukan check and balances terhadap kekuasaan pemerintahdanmemberikan kontribusi yang memperkuat unsur (komponen) lainnya. Civil society juga merupakan penyalur partisipasi masyarakat dalam aktivitas sosial dan ekonomi kemudian mengorganisir mereka ke dalam suatu kelompok yang lebih potensial yang memonitor lingkungan, kelangkaan sumber daya (resources depletion), polusi, dan kekejaman sosial lalu memberikan kontribusi terhadap pembangunan melalui distribusi manfaat yang merata dalam masyarakat dan menciptakan kesempatan baru bagi setiap individu guna memperbaiki ¿standar hidup' mereka. Hal terpenting lainnya adalah harapan yang akan mempengaruhi penerapan kebijakan publik, serta sebagai sarana yang melindungi (protecting) dan memperkuat (strengthening) kultur, serta keyakinan agama dan nilai-nilai yang berlaku di masyarakat.

Hubungan ketiga komponen tersebut dalam penyelenggaraan pemerintahan (governance) dapat dideskripsikan ke dalam bentuk skemaberikut ini:
Gambar 1

Hubungan Antar Stakeholders

dalam Penyelenggaraan Pemerintahan
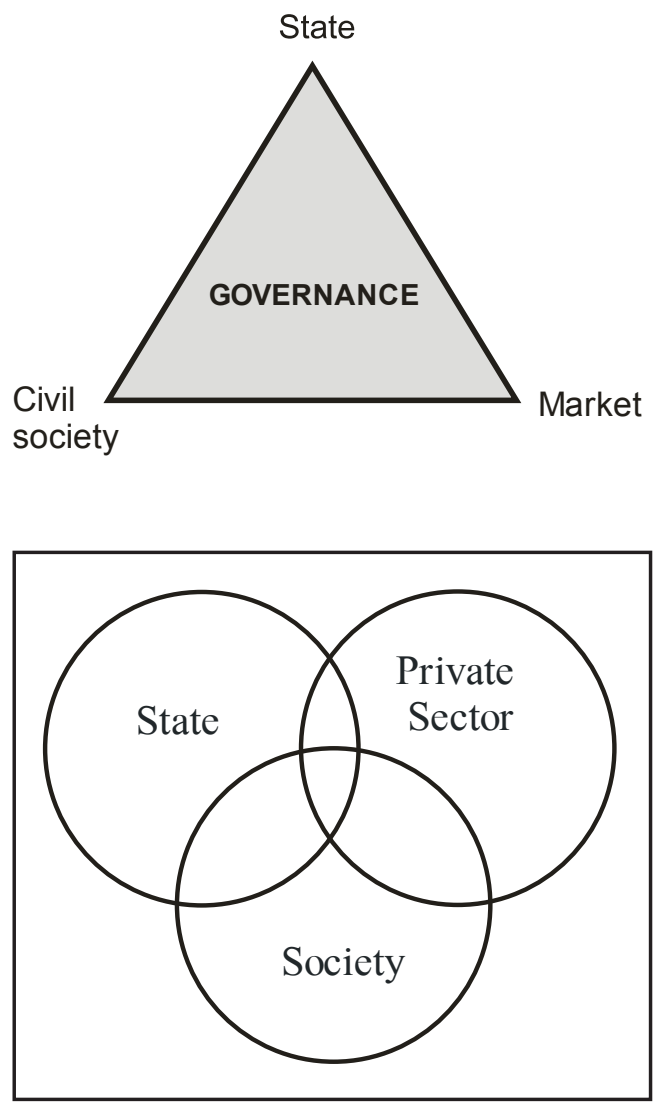

Berdasarkan uraian di atas, dapatlah disimpulkan bahwa wujud good governance adalah penyelenggaraan pemerint ahan negara yang solid dan bertanggung-jawab, serta efisien dan efektif dengan menjaga "kesinergian" interaksi yang konstruktif diantara ketiga domain (State, Private Sector, and Society).

Pemahamanmengenaigovernance sangat bervariasi tergantung dari fenomena dan bidang kajian yang membahasnya. Beberapa ragam 
penggunaan konsep governance, misalnya oleh World Bank dalam rekomendasinya yang dikenal sebagai 'good governance', debat dalam kajian hubungan internasional tentang ' $g o$ verning without government', diskusi mengenai kondisi kelembagaan untuk 'economic governance', visi baru sektor swasta/privat dalam bentuk 'corporate governance', wacana New Public Management (NPM), dan pola baru kerjasama dan kemitraan antara pemerintah dengan swasta (Rhodes, 1996; Kersbergen and Waarden, 2004).

Penerapan governance dalam penyelenggaraan pemerintahan selama ini lebih menganut konsep good governance sebagaimana yang dipromosikan oleh World Bank melalui beberapa agenda program multilateral di banyak negara. Leftwich dalam Chhotray and Stoker (2009) memandang good governance (GG) versi World Bank sebagai manajemen pembangunan dengan mensyaratkan adanya akuntabilitas (accountability), kerangka hukum (legal framework), informasi (information), dan transparansi (transparency). Prinsip ini menginspirasi United Nations for Development Programme (UNDP) untuk mengembangkannya lebih jauh menjadi sembilan karakteristik GG, yaitu partisipasi, penegakan hukum, transparansi, responsivitas, orientasi padakonsensus, persamaan, efektivitas dan efisiensi, akuntabilitas dan visi strategis. Governance secara umum dikenal melalui variasi prinsip-prinsip yang terkandung di dalamnya (Hyden,et.al, 2004).

Sederet prinsip tersebut dianut dan dipahami oleh pemerintah selama ini karena telah merasuki diskursusdiskursus pembangunan dan aktivitas lainnya yang didanai lembaga donor sebagai syarat pemberian bantuan. Pengalaman program penyesuaian struktural pada 1980-an, yaitu pasar yang kompetitif, terbuka, dan bebas yang diawasi secara minimal oleh negara, telahmengukuhkan ant usiasme pengembangan GG di Indonesia (Suharko, 2005). Pemaknaan dan penerapan governance yang pro neoliberalisme seperti inilah yang ditengarai menjadi salah satu sumber permasalahan penyelenggaraan pemerintahan. Proses governance sebagai serangkaian tindakan aktor dituntut dapat lebih dipahami secara analitis dan empiris daripada hanya ditempatkan sebagai daftar prinsipprinsip yang harus diikuti.

Selama ini telah terjadi kekeliruan memahami governance sebagai dampak dari pemahaman pemerintah yang hanya terbatas pada prinsip-prinsip dalam good governance produk lembagainternasional.Padahalgovernance tidak hanya mengandalkan peraturan formal yang sarat hegemoni negara sebagaimana yang terjadi sekarang. Pemerintah harus belajar mengendurkan 'otot' kewenangan ketika berinteraksi dengan pihak nonpemerintah dan tidak merasa dominan superior di atas stakeholder lainnya. 
Bertolak dari pemikiran tersebut, pemahaman governance dalam penelitian ini dimulai dari definisi yang lebih substansial sebagaimana yang dikemukakan oleh Chhotray dan Stoker (2009:3), yaitu:

Governance is about the rules of collective decisionmaking in settings where there are a plurality of actors or organisations and where no formal control system can dictate the terms of the relationship between these actors and organisations (governance adalah mengenai serangkaian aturan pengambilan keputusan bersama dimanaterdapat banyak aktor atau organisasi dan tidak ada sistem pengawasan formal yang mampu memaksa terjadinya hubungan antarbeberapa aktor atau organisasi tersebut).

Terdapat empat elemen dari definisi di atas yang perlu diketahui lebih jauh. Pertama, aturan (rules) yang bisa berbentuk formal hingga informal merupakan alat penjaga komitmen dan stabilitas relasi antaraktor. Dalam mempelajari governance, pengaturan formal berkaitan dengan strukturpengambilan keputusan dan informal menyangkut praktek dan kebiasaan keseharian. Kombinasi keduanya mempengaruhi cara sekelompok orang menentukan apa yang harus diputuskan, bagaimana memut uskannya, dan siapa yang harus mengambil keputusan tersebut.
Kedua,konsepkolektif(collective) menunjuk pada keputusan bersama yang diambiloleh sekelompokindividu melalui berbagai mekanisme mencapai kesepakatan atas hasil yang dituju. Keputusan bersama memuat berbagai isu yang saling mempengaruhi dan mengawasi namun harus diterima dan dipertanggungjawabkan. Ketiga, pengambilan keputusan (decisionmaking) bukan hanya keputusan formal namun juga termasuk praktek pelaksanaan sehari-hari dalam suatu sistem atau organisasi. Keputusan atas sesuatu mensyaratkan adanya aturan mengenaisiapayangdapatmemutuskan dan bagaimana ia mempertanggungjawabkannya.Keempat, tidak ada sistem pengawasan formal yang dapat memaksa hubungan yang terjadi dan hasilnya (no formal control system can dictate). Prinsip demokrasi berlaku disini ketika tidak ada satu pihak yang memaksakan dan menekan pihak lain seperti pemerintahan monokrasi.

Karakteristik interaksi sosial dalam governance lebih mengandalkan negosiasi, komunikasi, dan pengaruh hegemonik daripada petunjuk pengawasan yang ketat dan mengikat. Ketergantungan dalam kehidupan menjadikan mekanisme pengambilan keputusan bersama menjadi penting dalam aktivitas manusia.

Pemahaman governance seperti telah dijelaskan di atas, sejalan dengan perspektif network. Dalam pandangan Sorensen dan Torfing (2007), governance network adalah: 1) 
artikulasi saling ketergant ungan secara horizontal antara beberapa aktor otonom; 2) interaksi berlangsung melalui negosiasi; 3) terjadi dalam suatu at uran, normatif, kognitifdan kerangka imajiner; 4) bersifat mengatur sendiri (self-regulating) di dalam batas-batas dariageneksternal;dan5)berkontribusi bagi produksi tujuan publik.

Governance network dapat dibedakan dari bentuk governance lainnya, seperti terlihat dalam Tabel 1.

Tabel 1

\section{Perbedaan Pola Governance}

\begin{tabular}{|c|c|c|c|}
\hline & $\begin{array}{c}\text { Hierarki } \\
\text { (Hierarchy) }\end{array}$ & $\begin{array}{c}\text { Pasar } \\
\text { (Market) }\end{array}$ & $\begin{array}{l}\text { Jejaring } \\
\text { (Network) }\end{array}$ \\
\hline $\begin{array}{l}\text { Koordi- } \\
\text { nasi }\end{array}$ & $\begin{array}{l}\text { Tunggal } \\
\text { Terpusat } \\
\text { (unicentric) }\end{array}$ & $\begin{array}{l}\text { Tidak } \\
\text { Tunggal } \\
\text { (multicen- } \\
\text { tric) }\end{array}$ & $\begin{array}{l}\text { Plural } \\
\text { (pluri- } \\
\text { centric) }\end{array}$ \\
\hline $\begin{array}{l}\text { Hubung-an } \\
\text { antar aktor }\end{array}$ & Subordinasi & $\begin{array}{l}\text { Tidak } \\
\text { terikat }\end{array}$ & $\begin{array}{l}\text { Saling } \\
\text { ketergan- } \\
\text { tungan }\end{array}$ \\
\hline $\begin{array}{l}\text { Dasar } \\
\text { Keputus- } \\
\text { an }\end{array}$ & $\begin{array}{l}\text { Nilai } \\
\text { substansial }\end{array}$ & Prosedur & Negosiasi \\
\hline $\begin{array}{l}\text { Dasar } \\
\text { Kerelaan } \\
\text { Hubung-an }\end{array}$ & Sanksi hukum & $\begin{array}{l}\text { Sanksi } \\
\text { ekonomi }\end{array}$ & $\begin{array}{l}\text { Keperca- } \\
\text { yaan dan } \\
\text { kewajiban }\end{array}$ \\
\hline $\begin{array}{l}\text { Basis } \\
\text { Teoritis }\end{array}$ & $\begin{array}{l}\text { Weberian/ } \\
\text { Neo Weberian } \\
\text { Model }\end{array}$ & $\begin{array}{l}\text { New Public } \\
\text { Manage- } \\
\text { ment }\end{array}$ & $\begin{array}{l}\text { Whole-of- } \\
\text { Govern- } \\
\text { ment }\end{array}$ \\
\hline Pola Pikir & Regulasi & Kompetisi & $\begin{array}{l}\text { Kolaborasi } \\
\text { dan } \\
\text { Koordinasi }\end{array}$ \\
\hline $\begin{array}{l}\text { Hubungan } \\
\text { Pemerin- } \\
\text { tah dengan } \\
\text { Masya- } \\
\text { rakat }\end{array}$ & $\begin{array}{l}\text { Kewenangan, } \\
\text { peraturan, } \\
\text { kewajiban }\end{array}$ & $\begin{array}{l}\text { Pelayanan } \\
\text { terhadap } \\
\text { Pelanggan } \\
\text { (costumers } \\
\text { of services) }\end{array}$ & $\begin{array}{l}\text { Pemang-ku } \\
\text { kepenting- } \\
\text { an (stake- } \\
\text { holders) } \\
\text { termasuk } \\
\text { masya- } \\
\text { rakat }\end{array}$ \\
\hline
\end{tabular}

Sumber: diolah dari Sorensen dan Torfing (2007).

Tabel 1 menunjukkan governance network memiliki karakteristik yang berbeda dengan pola hierarki dan pasar dimana koordinasi dibangun dari pluralitas aktor, hubungan bersifat saling ketergantungan, negosiasi sebagaidasarkeputusan, sertadilandasi kepercayaan dan kewajiban. Masyarakat ditempatkan sebagai pemangku kepentingan bersama pihak lainnya sehingga ada kompleksitas aktor yang saling berinteraksi.

\section{Jejaring Kebijakan (Policy Network)}

Tat a pemerintahan di era sekarang ini harus memperhatikan beberapa perubahan kontemporer, seperti demokratisasi, desentralisasi, dan liberalisasi ekonomi. Perubahan tersebut menempatkan posisi pemerintah bukan satu-satunya aktor yang mengelola kekuasaan negara dan bukan satusat unya pihak yang bisa menyelesaikan masalah publik tanpa peran-serta pemangku kepentingan lainnya. Dalam konteks ini, pemerintah perlu membangun sinergi dalam pola relasi yang lebih setara mengingat masingmasing pelaku memiliki otonomi (Rhodes, 1997).

Berangkat daripemikirantersebut, pendekatan jejaring (network approach) menjadi salah satu solusi menyelesaikan masalah yang komplek. Aktor tunggal bukan ide yang tepat untuk menyelesaikan masalah, karena aktor tunggal hanya memiliki sumber daya terbatas dalam menjalankan peran secara optimal. Sehingga, 
interaksi beberapa aktor menjadi penting diselenggarakan dalam kerangka saling ketergantungan dan pertukaran sumber daya. Sinergi perlu dibangun dengan kemampuan mengelola jaringan (networking) demi membangun energi bersama (collective energy) untuk mencapai tujuan bersama (collective gain) sebagai penjabaran kepentingan publik. Kegagalan mengelola jaringan akan mengarah pada kegagalan tata pemerintahan (governance).

Menurut Kickert bahwa tidak mungkin dihindari menyelesaikan permasalahan yang komplek lintas organisasi tanpa jaringan sehingga kehadiran aktor dalam jejaring yang saling ketergantungan satu dengan yang lainnya mutlak diperlukan (Kickert et al,1997:2).

"Actor in networks is interdependent because they cannot attain their goals by themselves, but need the resourses of the actor to do so. Interdependency is bases on the distribution of recourses over various actor, the goals they pursue and perceptions of their recourses dependencies."

Pembahasan tentang jejaring memposisikan dua pihak atau lebih sebagai sebuah entitas politik yang berkedudukan sama atau setara sehingga jejaring mengedepankan tercapainya tujuan/kepentingan bersama. Di dalam suatu jejaring, individu dan lembaga dihubungkan dengan yang lain dengan satu tujuan atau didasarkan kepentingan bersama.

Ketergantungan antara individu dan organisasi memungkinkan mereka berinteraksi untukmembangunjejaring yang lebih baik. Jejaring tidak akan terwujud menjadi sinergi antaraktor ketika aktor-aktor kurang peduli terhadap ketergantungan mereka atas lembaga lain. Perbedaan dan ketidaksepahaman dalam persepsi diantara aktor dapat menyebabkan konflik dan membatasi interaksi, hanya ketika aktor-aktor mampu membawa persepsi bersama dan merumuskan tujuan serta kepentingan bersama akan berujung pada outcome yang memuaskan.

Menurut Rhodes, dalam Kickert et.al.(1997), bahwakarakteristikdalam jejaringadalah, pertama, interdependensi (ketergant ungan) di ant ara aktor/ organisasi yang terlibat. Kedua, interaksi yang berkelanjutan diantara keanggotaan yang bertukar sumber daya dan negosiasi dengan berbagai tujuan. Ketiga, interaksi yang diatur oleh aturan main dan membangun kepercayaan. Keempat, tingkat otonomi yang signifikan dari intervensi negara. Karakteristik ini yang mengilhami pemikiran network policy dalam menyelesaikan masalah antarinstitusi.

Fenomena dalam tulisan ini adalah kompleksitas dalam proses kebijakan pengangkutan batubara di Provinsi Jambi. Kompleksitas tersebut dapat dilihat dari aspek aktor yang terlibat, polarelasiyangterjadi,strategi 
interaksi, kepentingan, dan sumber daya masing-masing, Dengan karakteristik seperti ini, secara konseptual dapat dikaji dengan konsep jejaring kebijakan (policy network). Jejaring kebijakan fokus menganalisis proses kebijakan publik bertolak dari pemikiran distribusi kekuasaan dan saling ketergantungan (distribution of power and interdependencies), fitur organisasi (organizational features), dan hubungan antar-organisasi (interorganizational relations).

Menurut Kickert et.al. (1997), jejaring kebijakan mengkaji pola relasi sosial antarbeberapa aktor yang memiliki ketergantungan satu sama lain dimana mereka berperan di dalam proses kebijakan publik. Sementara menurut Enroth (2011), jejaring kebijakan memiliki karakteristik, yaitu adanya saling ketergantungan (interdependence), koordinasi (coordination), dan bersifat plural (pluralism). Dengan demikian, jejaring kebijakan melihat kebijakan sebagai suatu proses yang kontekstual (contextualization of the policy process) dimana terdapat kompleksitas hubungan (relations complexity) antarberbagai aktor, baik formal maupun informal, dengan tujuan masing-masing (variety of actors each with their own goals) yang memiliki ketergantungan satu sama lain (interdependency).

\section{METODOLOGI}

Metode yang digunakan dalam kajian ini adalah metode deskriptif dengan pendekatan kualitatif. Kajian ini tergolong desk-study yang mengutamakan data sekunder dari dokumen peraturanperundang-undangandisertai arsip pemberitaan dari media massa lokal.

Pengumpulan data sekunder dilakukan dalam jangka waktu bulan April-Mei 2014. Keabsahan data dijamin dengan teknik triangulasi pada sumber data dan metode.

Analisis data menggunakan analisis kualitatif dimana data yang diperoleh akan diklasifikasi, direduksi, dikategorisasi, dipetakan, dan diinterpretasi untuk kemudian ditarik simpulan dengan berlandaskan teori jejaring kebijakan.

\section{PEMBAHASAN}

\section{Deskripsi Kebijakan Pengangkutan Batubara di Provinsi Jambi}

Kebijakan mengenai pengangkutan batubara diwujudkan dalam bentuk Perda Provinsi Jambi Nomor 13 Tahun 2012 tentang Pengaturan PengangkutanBatubaradalamProvinsi Jambi. Perda ini perlu dilaksanakan agarterbangun harmonisasiantar pemangku kepentingan sebagai suatu kesatuan gunamendorong upaya percepatan pembangunan sosial dan ekonomi daerah. 
Perdaini sebagai sebuah kebijakan yang bertujuan untuk:

a. Mewujudkan keamanan, ketertiban, dan keselamatan pengguna jalan;

b. Mewujudkan sistemjaringanjalan yang berdaya guna dan berhasil guna demi terselenggaranya sistem transportasi yang terpadu;

c. Mewujudkan sungai sebagai jalur transportasi angkutan batubara;

d. Mendorong upaya percepatan pembangunan sosial dan ekonomi daerah; serta

e. Mendorong dan memberikan dukungan kepada pelaku usaha untuk membangun jalan khusus angkutan batubara.

Setiap pengangkutan batubara dalam Provinsi Jambi wajib melalui jalan khusus atau jalur sungai. Kewajiban melalui jalan khusus harus siap selambat-lambatnya Januari 2014. Apabila jalan khusus tersebut belum dibangun atau belum dapat digunakan, makapengangkutanbatubaradilakukan melalui jalan umum tertentu yang ditetapkan oleh Kepala Daerah sesuai dengan kewenangannya. Sedangkan unt uk jalur sungai, jika tidak memadai untuk pengangkutan batubara, maka dapat dilakukan melalui jalan umum tertentu yang ditetapkan oleh Kepala Daerah sesuai dengan kewenangannya. Jalan umum tertentu yang dimaksud adalah jalan yang menghubungkan jarak terdekat dari lokasi tambang menuju ke tempat penumpukan batubara di sungai terdekat dari lokasi tambang tersebut.
Khusus untuk pengangkutan batubara dari lokasi tambang di Kabupaten Bungo dan Kabupaten Tebo dapat melalui jalan umum tertentu, yaitu sebagai berikut:

a. Dari Kabupaten Bungo melalui Jalan Muaro Bungo-Muara Tebo menuju ke ruas jalan Simpang Niam-Lubuk Kambing-Merlung-Pelabuhan di Taman Rajo Kecamatan Tungkal Ulu Kabupaten Tanjung Jabung Barat.

b. Dari Kabupaten Tebo menuju ke ruas jalan Simpang Niam-Lubuk Kambing-Merlung-Pelabuhan di Taman Rajo Kecamatan Tungkal Ulu Kabupaten Tanjung Jabung Barat.

c. Khusus pengangkutan batubara dari lokasi tambang ke wilayah Sumatera Barat dapat melewati jalan umum dengan tetap mempedomani peraturan perundangundangan yang berlaku.

Sedangkan untuk pengangkutan batubara dari lokasi tambang di Kabupaten Merangin, Kecamatan Sarolangun, Kabupaten Batang Hari, dan Kabupaten Muaro Jambi melalui jalursungai yangterdapat di Kabupaten yang bersangkutan menuju pelabuhan terminal batubara untuk diangkut ke luar Provinsi Jambi. Pengangkutan batubara dari lokasi tambang menuju tempat penumpukan batubara dapat menggunakan jalan umum yang ditetapkan oleh Bupati yang bersangkutan sesuai kewenangannya.

Setiap pelaku usaha yang melanggar 
ketentuan tersebut dapat dikenakan sanksi administrasi, berupa:

a. Teguran tertulis;

b. Pengurangan rencana produksi yang diusulkan pada tahun berikutnya;

c. Pencabutan izin usaha pertambangan, yang meliputi:

1) Pencabutan izin usaha pertambangan operasi produksi.

2) Pencabutan izin operasi khusus pengangkutan dan penjualan.

3) Pencabutan izin usaha jasa pengangkutan pertambangan.

Pengaturan ini selanjutnya diperkuat oleh Peraturan Gubernur Jambi (Pergub) Nomor 18 Tahun 2013 tentang Tata Cara Pelaksanaan Pengangkutan Batubara. Pergub ini memberikan petunjuk mengenai pelaksanaan pengangkutan batubara melalui jalan umum dan jalur sungai sertamemberikankesempatankegiatan usaha pertambangan batubara dapat terus dilaksanakan. Selain itu, Pergub inijugamempertegas peran pemerintah daerah melakukan pembinaan, pengaturan, pengawasan, pengendalian, dan penindakan terhadap angkutan batubara agar dapat berjalan sesuai dengan ketentuan yang berlaku melalui pembentukan Tim Terpadu yang terdiri dari unsur Dinas Perhubungan, Dinas ESDM, TNI, POLRI, Satpol PP, dan unsur terkait lainnya.

\section{Pemetaan Aktor dari Dimensi Sumber Daya, Kepentingan, dan Strategi}

Kebijakanpengangkutanbatubara di Provinsi Jambi dapat dilihat sebagai suat uproses kebijakanyangmelibatkan banyak aktor dengan kepentingan masing-masing (interests) dimana mereka memiliki sumber daya (resources) dan strategi (strategies) dalam berinteraksi. Oleh karena itu, analisis jejaring kebijakan dapat dilakukan dengan pemetaan sumber daya, kepentingan, dan strategi setiap aktor yang terlibat dalam kebijakan. Polarelasi yang terjadi selamainteraksi kebijakan juga perlu dilakukan agar analisis kebijakan dengan pendekatan jejaring lebih jelas dan komprehensif.

Secara sederhana, kompleksitas dalamjejaring kebijakanpengangkutan batubara di Provinsi Jambi dapat dilihat pada tabel berikut: 
Tabel 2

\section{Kompleksitas Kebijakan Pengangkutan Batubara di Provinsi Jambi}

\begin{tabular}{|c|c|c|c|}
\hline AKTOR & SUMBER DAYA & KEPENTING-AN & STRATEGI \\
\hline $\begin{array}{l}\text { Pemerintah } \\
\text { Provinsi }\end{array}$ & $\begin{array}{ll}\text { o } & \text { Kewenangan regulasi } \\
\text { o } & \text { Wakil Pemerintah } \\
& \text { Pusat } \\
\text { o } & \begin{array}{l}\text { Otoritas penggunaan } \\
\text { jalan }\end{array}\end{array}$ & $\begin{array}{l}\text { o Infrastruktur jalan } \\
\text { tidak rusak oleh } \\
\text { angkutan batubara } \\
\text { o Pendapatan daerah } \\
\text { dari batubara } \\
\text { o Kepercayaan publik } \\
\text { o Pembuktian Visi Misi } \\
\text { Infrastruktur }\end{array}$ & $\begin{array}{l}\text { o Memberlakukan Perda } \\
\text { dan Pergub pengangkutan } \\
\text { batubara } \\
\text { o Memberi tenggang waktu } \\
\text { pengusaha membuat jalan } \\
\text { khusus angkutan batubara }\end{array}$ \\
\hline $\begin{array}{l}\text { Pemerintah } \\
\text { Kabupaten }\end{array}$ & $\begin{array}{l}\text { o Kewenangan regulasi } \\
\text { o Otoritas penggunaan } \\
\text { jalan }\end{array}$ & $\begin{array}{l}\text { o Infrastruktur jalan } \\
\text { tidak rusak oleh } \\
\text { angkutan batubara } \\
\text { o Pendapatan daerah } \\
\text { dari batubara } \\
\text { o Kepercayaan publik }\end{array}$ & $\begin{array}{l}\text { o Menetap-kan/belum } \\
\text { menetap-kan Perbup } \\
\text { tentang jalan yang bisa } \\
\text { dilalui angkutan barubara }\end{array}$ \\
\hline $\begin{array}{l}\text { Pelaku Usaha } \\
\text { Batubara }\end{array}$ & $\begin{array}{l}\text { o Kontribusi bagi penda- } \\
\text { patan daerah } \\
\text { o Pendukung pereko- } \\
\text { nomian daerah }\end{array}$ & $\begin{array}{l}\text { o Distribusi lebih efisien } \\
\text { o Tidak mau rugi } \\
\text { o Jarak lebih dekat } \\
\text { o Diperbolehkan } \\
\text { melintasi jalan umum }\end{array}$ & $\begin{array}{l}\text { o Mengancam menggugat } \\
\text { Perda dan Pergub ke PTUN } \\
\text { o Berpegang pada izin usaha }\end{array}$ \\
\hline Tim Terpadu & $\begin{array}{l}\text { o Kewenangan penga- } \\
\text { wasan dan penin-dakan }\end{array}$ & $\begin{array}{l}\text { o Melaksanakan } \\
\text { tupoksi pembinaan, } \\
\text { pengawasan, dan } \\
\text { penindakan } \\
\end{array}$ & $\begin{array}{l}\text { o Razia } \\
\text { o Menilang truk yang } \\
\text { melanggar }\end{array}$ \\
\hline $\begin{array}{l}\text { Sopir Truk } \\
\text { Batubara }\end{array}$ & $\begin{array}{l}\text { o Operator aktivitas } \\
\text { angkutan batubara }\end{array}$ & $\begin{array}{l}\text { o Rute yang lebih dekat } \\
\text { o Tuntutan pekerjaan }\end{array}$ & $\begin{array}{ll}\text { o } & \begin{array}{l}\text { Demonstrasi besar- } \\
\text { besaran }\end{array} \\
\text { o } & \text { Memblokir jalan lintas } \\
& \text { Sumatera } \\
\end{array}$ \\
\hline Kelompok Warga & o Dukungan dan tuntutan & $\begin{array}{l}\text { o Jalan umum tidak } \\
\text { rusak } \\
\text { o Tidak macet } \\
\text { o Tidak ada gangguan } \\
\text { truk batubara }\end{array}$ & $\begin{array}{ll}\text { o } & \text { Aksi pemblokir-an jalan } \\
\text { o } & \text { Menuntut Pemerintah } \\
& \text { Provinsi Jambi agar tegas } \\
& \text { menegak-kan Perda }\end{array}$ \\
\hline
\end{tabular}

Kerumitan dalam kebijakan pengangkutan batubara di Provinsi Jambi dapat diurai dengan tabel pemetaan di atas yang memperjelas apa saja sumber daya dan kepentingan tiap-tiap aktor kebijakan disertai bagaimana strategi yang dilakukan di dalam proses interaksi kebijakan. Dari pemetaan tersebut ada beberapa hal yang perlu digarisbawahi, yaitu: pertama, kebijakan pengangkutan batubara adalah kebijakan yang berhubungan erat dengan kepentingan publik, khususnya keberlanjutan fasilitas publik infrastruktur jalan. Keberhasilan atau kegagalan implementasi kebijakan ini akan berdampak pada dukungan dan kepercayaan masyarakat kepada Pemerintah Daerah.

Kedua, Pemerintah Daerah sudah melakukan negosiasi dengan pelaku 
usaha dengan memberikan toleransi waktu pembuatan jalan khusus pengangkutan batubara, namun jalan khusus tidak juga terwujud. Hal ini disebabkan masih belum terjalin persamaan kepentingan antara Pemerintah Daerah dan pelaku usaha. Pemda lebih mengedepankan kepentingan publik sesuai visi dan misi, sementara pelaku usaha memegang teguh kepentingan ekonomi kalkulatif unt ung rugi.

Ketiga, pada dasarnya sopir batubara berada pada posisi yang kurang menguntungkan karena hanya menjadi instrumen resistensi pelaku usaha terhadap kebijakan dengan cara mobilisasi aksi demonstrasi. Di lapangan, sopir berhadapan dengan Timdu sebagai pengawas pelaksanaan Perda dan juga berhadapan dengan warga yang protes dengan melakukan aksi blokir jalan. Dalam keadaan seperti ini, sopir dalam posisi terjepit di tengah, antara elit dan massa.

\section{Pemetaan Relasi Aktor Kebijakan}

Pemetaan sumber daya, kepentingan, dan strategi yang telah dilakukan sebelumnya, akan lebih komprehensif jika dilengkapi dengan pemetaanrelasiantaraktoryangterlibat dalam kebijakan pengangkutan batubara. Berikut ini skema pemetaan interaksi antaraktor kebijakan disertai pola relasi yang terjadi.
Gambar 2

\section{Pemetaan Interaksi Antar Aktor Kebijakan Pengangkutan Batubara}
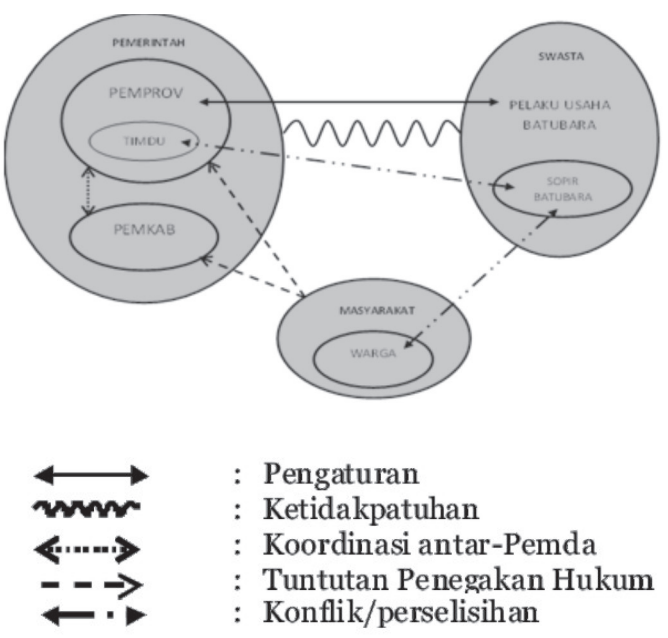

Pemetaan di atas membantu kita mengetahui pola interaksi yang terjadi antarsesama pemangku kepentingan kebijakan pengangkutan batubara di Provinsi Jambi. Paling tidak ada beberapa catatan hasil pemetaan di atas, antara lain:

1. Dalam implementasi Perda, Pemprov Jambi membutuhkan koordinasi serta dukungan regulasi dari Pemkab sehubungan dengan ruas jalan yang diperbolehkan dilalui angkutan batubara.

2. Sopir batubara menjadi alat pelaku usaha untuk melakukan respon ketidakpatuhan dan resistensi terhadap kebijakan Pemda.

3. Perselisihan yang muncul ke permukaan justru terjadi di dua level, yaitu antara Timdu dan sopir batubara; antara warga masyarakat dan sopir batubara.

4. Sumber permasalahan ialah adanya perbedaan pandangan antara 
Pemerintah Daerah dan pelaku usaha batubara.

Permasalahan kebijakan yang telah terjadi dapat diurai setelah mengetahui dimana titik utama relasi aktor yang perlu diintervensi oleh kebijakan lanjutan. Kunci penyelesaiannya ada pada pelaku usaha yang harus konsisten dengan kebijakan yang telah ditetapkan. Kebijakan ini telah melalui proses yang cukup panjang melalui diskusi disertai dengar pendapat antara Pemerintah Provinsi dan pelaku usaha batubara. Hal ini terbukti dengan adanya toleransi waktu satu tahun yang diberikan Pemprov kepada pengusaha untuk membuat jalan khusus batubara. Pemberian tenggat waktu dalam suatu kebijakan dapat dimaknai sebagai suatu kebijaksanaan dalam penyelesaian masalah.

Pemberian tenggat waktu tidak otomatis melepaskan tanggung-jawab pemerintah daerah terhadap urusan pengangkutan batubara. Pemerintah Provinsi hendaknya tidak lepas tangan dengan mengatakan bahwa selanjutnya dikembalikan kepada kewenangan Bupati.HubunganPemerintahProvinsi dengan Kabupaten/Kota bukan hubungan otonom independen satu sama lain sehingga harus selalu dalam satu kesatuan fungsi pemerintahan. PemerintahProvinsitetapmenjalankan peran sebagai wakil Pemerintah Pusat di Daerah yang memiliki kewenangan koordinasi, pembinaan, dan pengawasan terutama menyangkut urusan lintas Kabupaten/Kota.

\section{PENUTUP}

Pembahasan yang telah dilakukan sebelumnya, mengantarkan penulis menarik beberapa simpulan, antara lain:

1. Kompleksitas permasalahan pengangkutan batubara di Provinsi Jambi terlihat dari adanya pelanggaran Perda oleh pengusaha batubara sehingga masih merusak jalan umum, aksi demonstrasi sopir truk batubara, aksi protes blokir jalan oleh warga, dan upaya pengusaha untuk menggugat Perda Pengangkutan Batubara.

2. Sumber permasalahan ialah adanya perbedaan pandangan antara Pemerintah Daerah dan pelaku usaha batubara. Perselisihan yang muncul ke permukaan justru terjadi di dua level, yaitu antara Timdu dan sopir batubara; antara warga masyarakat dan sopir batubara. Pada dasarnya, sopir batubara menjadi alat pelaku usaha untuk melakukan respon ketidakpatuhan dan resistensi terhadap kebijakan Pemda.

Permasalahan kebijakan yang telah terjadi dapat diurai setelah mengetahui dimana titik utama relasi aktor yang perlu diintervensi oleh kebijakan lanjutan. Kunci penyelesaiannya ada pada pelaku usaha yang harus konsisten dengan kebijakan yang telah ditetapkan.

Dalam tata kelola pemerintahan di daerah (local governance), 
dibutuhkan hubungan antarjenjang pemerintahan (intergovernmental relations) yang harmonis dan kondusif sehingga dapat mendukung pelaksanaan fungsi pemerintahan. Dengan hubungan koordinasi yang baik, pelaksanaan peraturan, pembangunan, pemberdayaan, dan pelayanan publik akan lebih sistematis, terpadu, sinkron, dan tidak saling tumpang tindih. Dalam implementasi Perda pengangkutan batubara, Pemprov Jambi membutuhkan koordinasi serta dukungan regulasi dari Pemkab sehubungan dengan ruas jalan yang diperbolehkan dilalui angkutan batubara.

Hubungan antara Pemerintah Daerah dan pihak nonpemerintah, yaitu swasta dan masyarakat sipil, harus bersifat konstruktif dan kolaboratif dengan mengedepankan prinsip partisipasi, transparansi, dan akuntabilitas selama proses kepemerintahan. Hal ini hendaknya terus dikembangkan dalam semua aspek praktek pemerintahan daerah agar good local governance dapat terlembagakan dan berkelanjutan.

Penulis berpandangan bahwa pelaku usaha, perwakilan warga, pemda provinsi, dan kabupaten/kota harus kembali duduk bersama untuk memperjelas komitmen pengelolaan pengangkutan batubara. Kepentingan publik harus diutamakan dalam artian kebijakan Perda harus diterapkan secara konsisten. Penegakan hukum menjadi kuncinya karena pelaku usaha juga merupakan objek hukum yang harus mematuhi peraturan yang telah dirumuskan bersama.

Jalur yang telah ditetapkan di dalam Perda harus representatif bagi kepentingan pelaku usaha. Langkahlangkah penyediaan alternatif jalur angkutan batubara seperti revitalisasi jalur sungai ataupun rel kereta api harus mulai dilakukan oleh pemerintah daerah. Dukungan Pemerintah Pusat menjadi penting untuk mewujudkan infrastruktur transportasi sungai dan rel kereta api di Provinsi Jambi.

Jalur sungai sebenarnya masih bisa dilalui oleh kapal tongkang pengangkut batubara sehingga komitmen pengusaha dan ketegasan Pemdaadalahkunciawalpengangkutan melalui jalur sungai. Konsekuensi yang perlu ditindaklanjuti ialah sopir yang kehilangan mata pencaharian. Substitusi pekerjaan bagi sopir batubara harus diupayakan pengusaha bersama dengan pemda karena merupakan konsekuensi suatu kebijakan.

\section{DAFTAR PUSTAKA}

Bevir, Mark (ed.). 2007. The Encyclopedia of Governance. California: Sage Publication.

ChHotray, Vasudha and Gerry Stoker. 2009. Governance Theory and Practice: A Cross Disciplinary Approach. Hampshire \& New York: Palgrave MacMillan.

Enroth, Henrik. 'Policy Network 
Theory' in Bevir, Mark. 2011. The SAGE Handbook of Governance. London: Sage.

Hyden, G., Court, J. and Mease, K. (eds). 2004. Making Sense of Governance: Empirical Evidence from 16 Countries. Boulder and London: Lynne Rienner Publishers.

Jambi Independent. Surat Kabar Harian. 15/1/2014， 20/1/2014, $12 / 3 / 2014$.

Kickert, Walter J.M., Erik-Hans Klijn and Joop F.M. Koppenjan. 1997. Managing Complex Networks: Strategies for the Public Sector. London: Sage.

Lembaga Administrasi Negara. 2000. Akuntabilitas dan Good Governance: Modul Sosialisasi Sistem Akuntabilitas Kinerja Instansi Pemerintah (AKIP). Jakarta: Lembaga Administrasi Negara.
Nisjar S. Karhi. 1997. 'Beberapa Catatan tentang "Good Governance".Jurnal Administrasi dan Pembangunan, Vol. 1 No. 2, 119.

Osborne, David and Ted Gabler. 1992. Reinventing Government: How the Enterpreneurial Spirit IS Transforming the Public Sector. MA: Addison Wesley Longman, Inc.

Sorensen, E. and Torfing, J. 2007. Theories of Democratic Network Governance. Hampshire and New York: Palgrave Macmillan.

Suharko. 2005. 'Masyarakat Sipil, Modal Sosial, dan Tata Pemerintahan yang Demokratis'. Jurnal Ilmu Sosial dan Ilmu Politik. Vol. 8 (3), p. 263-290.

United Nations Development Programme's. 1997. 'Governance for Sustainable Human Development'. Policy Paper UNDP. 